\title{
Articles
}

\section{"I gained a skill and a change in attitude": A Case Study Describing How an Online Continuing Professional Education Course for Pharmacists Supported Achievement of Its Transfer-to-Practice Outcomes}

\author{
Pia Zeni Marks, Brad Jennings, University of Waterloo \\ Barbara Farrell, University of Ottawa; University of Waterloo; \\ Bruyère Research Institute, Ottawa \\ Natalie Kennie-Kaulbach, Dalhousie University \\ Derek Jorgenson, University of Saskatchewan; University of Ottawa \\ Jane Pearson Sharpe, Ontario Pharmacy Research Collaboration \\ Nancy Waite, University of Waterloo
}

\begin{abstract}
The convenience and flexibility of online learning clearly make it an attractive option for learners in professional development contexts. There is less clarity, however, about how it fares as a vehicle for enabling the applied, practice-oriented outcomes typically associated with professional development learning. This paper presents a case study describing how transfer-of-learning strategies were employed in a continuing professional education (CPE) course developed for practicing pharmacists, called ADAPT (ADapting pharmacists' skills and Approaches to maximize Patients' drug Therapy effectiveness). To gain insight into the extent to which learning was transferred to practice as a result of participation in the
\end{abstract}

\section{RÉSUMÉ}

La commodité et la souplesse de

l'apprentissage en ligne en font une option indéniablement attrayante pour les apprenants dans des contextes de développement professionnel. Il y a cependant moins de clarté quant à la façon dont ce type d'apprentissage s'en sort en tant que moteur pour rendre les résultats appliqués orientés vers la pratique généralement associés à l'apprentissage du perfectionnement professionnel. Le présent article présente une étude de cas décrivant comment des stratégies de transfert de l'apprentissage ont été utilisées dans un cours de formation professionnelle continue intitulé ADAPT (pour ADapting pharmacists' skills and Approaches to maximize Patients' drug Therapy

Canadian Journal of University Continuing Education | Vol. 40, No. 2, Fall 2014

Revue canadienne de l'éducation permanente universitaire I vol. 40, n², automne 2014

http://ejournals.library.ualberta.ca/index.php/cjuce-rcepu 
course, qualitative data were collected over a 12-month period from participants of the 2010 pilot offering of ADAPT. Participants reported making changes to their practice as a result of participating in the course, and they identified three course features as being particularly useful in facilitating practice transfer: providing learners with (i) a vision of targeted outcomes and skills, (ii) support to enable them to attain targeted outcomes and skills, and (iii) explicit preparation for action. effectiveness ou Adaptation des compétences et des approches des pharmaciens pour maximiser l'efficacité des thérapies médicamentées des patients) et créé pour les pharmaciens qui exercent. Pour avoir un aperçu de la mesure dans laquelle l'apprentissage s'est transformé en pratique à la suite de la participation au cours, des données qualitatives ont été recueillies sur une période de 12 mois auprès des participants de l'édition pilote 2010 d'ADAPT. Les participants ont déclaré avoir modifié leur pratique en raison de leur participation au cours, et ils ont identifié trois fonctions de cours comme étant particulièrement utiles pour faciliter le transfert de la pratique : fournir aux apprenants (i) une vision des résultats et des compétences visés, (ii) un appui qui leur permettra d'atteindre les résultats et les compétences visés et (iii) la préparation explicite à l'action visée.

\section{INTRODUCTION}

The merits of online learning for adult learners have long been acknowledged: online learning affords these learners, who often have significant work and family commitments, the convenience and flexibility they need to learn anytime, anywhere. As a result, it can open doors for professional development that had previously remained closed. Quite apart from these benefits, however, how does it fare as a vehicle for enabling applied, practice-oriented types of outcomes - the kinds of outcomes, in short, typically associated with professional development? And if these kinds of outcomes can be achieved in an online setting, what are the conditions under which they are facilitated? This paper explores these questions in the context of an online course developed for practicing pharmacists, called ADAPT (ADapting pharmacists' skills and Approaches to maximize Patients' drug Therapy effectiveness).

ADAPT was designed to meet the needs of practicing pharmacists in a rapidly evolving Canadian health-care environment. The emergence of interprofessional primary health-care teams and the expanding scopes of practice for pharmacists have precipitated many changes in pharmacists' roles and responsibilities (Task Force on a Blueprint for Pharmacy, 2008). The goal of ADAPT is to provide pharmacists with the patient-care and collaborative skills they need to take on these new roles with confidence (Farrell, Dolovich, Austin, \& Sellors, 2010). Specific skillbased outcomes in support of this goal include the abilities to

- provide comprehensive medication management,

- collaborate with health-care providers,

- interview and assess patients,

- make evidence-based clinical decisions,

Canadian Journal of University Continuing Education | Vol. 40, No. 2, Fall 2014

Revue canadienne de l'éducation permanente universitaire I vol. 40, n² 2, automne 2014

http://ejournals.library.ualberta.ca/index.php/cjuce-rcepu 
"I gained a skill and a change in attitude"

- document care, and

- develop and implement care plans.

Learners build these skills by engaging in course activities in groups $(n=15)$ over 18 weeks, guided and supported by a moderator who facilitates learners' participation in course activities, provides formative feedback on submitted work, and supports learners' application of course concepts to practice. Learners complete seven modules, which include multimedia presentations delivered by subject matter experts and practicing pharmacists, simulated patient encounter videos, moderated discussion activities, peer feedback activities, as well as guided interaction with specialized resources and tools (e.g., e-Therapeutics, evidence-based medicine databases, documentation templates, global rating scales).

\section{Literature ReView}

Given the practice-oriented nature of ADAPT's outcomes, course design (Farrell et al., 2012) was guided by the principles of experiential learning (Kolb \& Fry, 1975) and cognitive apprenticeship (Collins, Brown, \& Holum, 1991). The central insight of experiential learning is that learning occurs most effectively through a four-stage process of what Kolb (1984) calls "grasping experience and transforming it" (p. 41). This process: (i) begins with a concrete experience, whereby learners become engaged in a topic; (ii) is followed by reflective observation, through which they interpret the experience, then by (iii) abstract conceptualization, whereby they construct a general framework for the experience; and (iv) concludes with active experimentation, in which they apply their new-found theoretical frameworks in new situations (Kolb \& Fry, 1975). Experience is the starting point for learning. Cognitive apprenticeship also foregrounds the importance of experience: it is a process by which novice learners engage in authentic (i.e., realworld) activities under the guidance of experts whose involvement diminishes over time as learners gain competency. In this approach, expert practices are made visible through explicit modelling so that learners can "observe, enact and practice them with help from the teacher and other students" (Collins, Brown, \& Holum, 1991, p. 39).

ADAPT learners engage in authentic, expert practice by observing and in some cases interacting with simulated patient encounter videos, and by applying expert practitioners' tools, templates, and resources in their own practices, all under the guidance of moderators who act as guides and facilitators. These "practice-at-work" activities culminate, at the end of each module, in an Action Plan in which learners document the kinds of changes they intend to incorporate into their practices, based on the knowledge and skills learned in the module, as well as how they plan to achieve these changes. Peer interaction further supports learning, with group discussion boards providing a social space for participants to reflect on learning and to learn from one another.

While experiential learning and cognitive apprenticeship provide a design framework for practice transfer to flourish, Caffarella (2002) suggests that program and content design alone cannot guarantee transfer. Other factors, including the course's participants, the changes that are required to apply the learning, the organizational context, and community and societal forces can act as either facilitators of or barriers to transfer. Building on this research, this study explores the extent to which ADAPT participants were able to transfer their learning to practice, the course features that facilitated this transfer, and the factors that interfered with it.

Canadian Journal of University Continuing Education | Vol. 40, No. 2, Fall 2014

Revue canadienne de l'éducation permanente universitaire I vol. 40, n² 2, automne 2014

http://ejournals.library.ualberta.ca/index.php/cjuce-rcepu 


\section{Methodology}

A qualitative case study approach (Stake, 1995) was used to investigate these questions with participants from the 2010 pilot offering of the ADAPT online course $(n=86)$. Course participants were treated as a case of inquiry to explore (i) whether online experiences contributed to practice changes in the real world, (ii) which features of online learning facilitated real-world transfer of skills, and (iii) whether barriers arose that impeded this transfer. Qualitative data were collected with the informed consent of course participants over a 12-month period to gain insight into these questions. Both inductive and deductive content analysis methods were used to analyze the data. The study was approved by the University of Waterloo's Office of Research Ethics.

\section{Participants}

The 86 participants who enrolled in the pilot ADAPT program, offered September 2010 to January 2011, were invited to participate in the study. All 86 were pharmacists who practiced in a variety of settings, including community pharmacies, clinics, hospitals, and nursing homes (Jorgenson et al., 2012).

\section{Data Collection}

The study drew on three main sources of data: focus groups, conducted immediately after the course $(n=12)$, semi-structured telephone interviews, conducted 12 months after course completion $(n=10)$, and pre-interview online surveys, conducted one week prior to scheduled interviews $(n=10)$. In addition to these sources, study participants' Action Plans, submitted as part of their course work $(n=49)$, were used to verify the themes emerging from the primary sources of data.

\section{Focus groups}

Face-to-face focus group sessions were conducted in two locations-Saskatoon and Waterloo-in February 2011, one month after completion of the online course and just prior to two scheduled, culminating, face-to-face workshops. These one-day workshops provided opportunities for participants to interact with standardized patients and real physicians, to receive feedback on these interactions, and to engage in a final Action Plan discussion. (This component did not appear in subsequent offerings of the course.) Twenty-nine participants attended the workshops in Saskatoon and Waterloo; of these, 12 participated in the subsequent focus group sessions. Numbers were evenly distributed across the two focus groups: six participated in Saskatoon and six in Waterloo. The focus group questions were developed by the research team and explored participants' motivations for taking the course, as well as participants' perceptions of the effectiveness of specific course components in making changes to workplace practices. The focus group sessions were led by a research assistant and were audio-recorded and transcribed.

\section{Interviews}

Course participants, including those who took part in the focus groups, were invited to participate in telephone interviews approximately 12 months after course completion. Ten people participated. These interviews examined the types of practice changes learners were able to make and sustain as a result of their participation in ADAPT, the course components they considered most helpful in making those changes, and any barriers they encountered in implementing the changes. Interviews were audio-recorded and transcribed. Pre-interview surveys, in which interview participants documented the changes made to their practices as a result of the things they learned in each module, were administered one week prior to scheduled interviews. These were delivered via the online survey tool Survey Monkey (http://www.surveymonkey.com/).

Canadian Journal of University Continuing Education | Vol. 40, No. 2, Fall 2014

Revue canadienne de l'éducation permanente universitaire I vol. 40, n², automne 2014

http://ejournals.library.ualberta.ca/index.php/cjuce-rcepu 
"I gained a skill and a change in attitude"

\section{Action Plans}

Course participants submitted their Action Plans at the end of every module. In each Action Plan, learners set achievable practice change goals based on SMART criteria (Specific, Measurable, Attainable, Relevant, Time-Bound), as well as a timeline and a plan for achieving them (Appendix). Only the Action Plans of study participants who completed all seven modules were examined for analysis. In total, 49 Action Plans were downloaded for analysis at the end of the course.

All data were blinded by the research assistant prior to analysis.

\section{Data Analysis}

Data were analyzed both inductively and deductively through a consensus coding process designed to facilitate investigator triangulation (Burnard, 1991). This process began with researchers independently reviewing a subset of data for each data source and generating themes on these data. Seven researchers, representing various perspectives (pharmacists, instructional designers, and a research assistant), then compared themes and came to a consensus on the existence and meanings of themes. This step enhanced the validity of the categorizing method and minimized researcher bias. Themes were organized into coherent categories, and a codebook was developed for each data source. Codebooks were used to code the remaining data, line by line, using NVivo 9 software. The process was emergent in that no themes were defined before the data were analyzed - all themes derived directly from the data. Modifications to the themes were made as the coding got underway, with all decisions made by the research team after discussion. Illustrative quotes were selected for each theme, and the frequency of each theme was noted to determine its relative importance and to reveal general patterns in the data.

Data were then reduced by organizing the emergent themes into matrices deductively, based on the study's research questions and the themes that emerged from inductive analyses. Themes were summarized and synthesized into matrices across data sources and were discussed and validated by the research team. Through these discussions, a detailed description of the case emerged, which led to a theoretical understanding of the meaning of the case (Creswell, 1998).

\section{Scope}

As Stake (1995) and others (Krefting, 1991) point out, the goal of case study research is not to make generalizations but to deepen understanding of the case. With this in mind, and given that the data collected in this study rely on self-reported measures of change, it is important to clarify the scope of the results reported below. Rather than attempting to generalize a set of online course design principles that facilitate transfer-to-practice, the study is better understood as an example of how transfer-of-learning strategies were successfully employed in a particular CPE context.

\section{Results}

Themes are reported by research question and represent the most prevalent comments that emerged from the data.

Canadian Journal of University Continuing Education | Vol. 40, No. 2, Fall 2014

Revue canadienne de l'éducation permanente universitaire I vol. 40, n², automne 2014

http://ejournals.library.ualberta.ca/index.php/cjuce-rcepu 


\section{Research Question 1: \\ Did the online ADAPT program make a difference in pharmacists' workplace practices?}

Inductive analysis of the data revealed that changes in participants' workplace practices were reported across all data sources and especially in the longitudinal interviews. The top four changes reported by participants, as determined by prevalence in the data, include changes to direct patient care activities, enhanced communication skills, increased confidence, and improved interprofessional collaboration skills.

\section{Changes to Direct Patient Care Activities}

Participants reported making changes in the areas of interviewing patients, conducting medication reviews, making evidence-based decisions, conducting patient-centred care, and accepting responsibility for outcomes. For example, participant 8 (P8) described her ability to use evidence to inform her recommendations, while participant 9 (P9) spoke of increased confidence in conducting medication reviews and other patient-centred activities:

[I am] more comfortable in searching the primary care literature to support my recommendations. This demonstrates to the physicians and other health-care professionals I work with that my knowledge is current and applicable to their patients. (P8, Pre-Interview)

It had a very positive impact. It's got me doing more clinical activities, like counselling and in-depth chart review. I've also spoken with a few families of residents of personal care homes, which wasn't something I was really comfortable doing before. If you're not comfortable, sometimes you don't really make the effort. (P9, Interview)

\section{Enhanced Communication Skills}

Participants commented on being more systematic, concise, or frequent in their communication with physicians and other health-care professionals:

This entire course has allowed me to streamline my consultation and documentation skills. (P1, Action Plan)

Yes, I think being more organized overall, being able to concisely summarize a patient to a physician, is something I got better at, and I do attribute that to ADAPT. (P6, Interview)

\section{Confidence}

Participants reported greater confidence to offer recommendations about patient care, to branch out to new roles and services, to collaborate with other health-care professionals, and to teach newly acquired skills to others:

So I will quite often now try to get to the wards before the doctors leave, so if I have something I want to suggest or can't quite formulate in a note, I'll have a face-to-face conversation with them. (P9, Interview)

Canadian Journal of University Continuing Education | Vol. 40, No. 2, Fall 2014

Revue canadienne de l'éducation permanente universitaire I vol. 40, n², automne 2014

http://ejournals.library.ualberta.ca/index.php/cjuce-rcepu 
"I gained a skill and a change in attitude"

\section{Improved Interprofessional Collaboration Skills}

Participants reported better collaboration with physicians and other health-care professionals:

I am now using the nurse practitioners and dietitians as a resource, and it has helped me feel that I am part of the team. This has had the effect of helping me make better decisions for my patients. (P2, Pre-Interview)

\section{Were Changes Sustained?}

Interview participants reported that the changes they had made in their practice post-ADAPT were sustained one year later. Reasons for this included internal motivation, a supportive work environment, and the practicality of the concepts learned:

Interviewer: "What things helped you to sustain those changes?"

Participant: "The continuity of my job. I do it Monday to Friday. Also, my personality is such that I will try to do better all the time." (P6, Interview)

Participant: "I have an extremely supportive regional director of primary care who is always pushing me to get involved with more stuff. That's always good." (P7, Interview)

Participant: "I think that's one of the best things about ADAPT-it's really practical stuff, so once you learn it and once you start doing it, you document every day, so you're going to keep doing that." (P9, Interview)

\section{Barriers to Implementing Changes}

Some participants reported barriers to implementing changes in their practices. Principal among these were a lack of practice continuity, time constraints, restrictive funding models, and challenges with interprofessional collaboration:

And relationships ... it's all about relationships. You need time and continuity. (P6, Interview)

Biggest issue right now is finding the time to do all this. (P11, Action Plan)

Well, money is always a barrier. My mindset is a barrier in terms of charging the patient for services. (P7, Interview)

I guess the unfamiliarity of the pharmacist's role and understanding what the pharmacist can bring to the clinic, from all people's points of view. That's the biggest thing.

(P6, Interview)

\section{Research Question 2: What aspects of the ADAPT program contribute to pharmacists implementing workplace practice changes?}

Three factors emerged as being important to learners in facilitating transfer of learning to practice. Learners reported benefiting from acquiring a vision of the targeted outcomes and skills, support for transfer of learning, and preparation for action.

Canadian Journal of University Continuing Education | Vol. 40, No. 2, Fall 2014

Revue canadienne de l'éducation permanente universitaire I vol. 40, n², automne 2014

http://ejournals.library.ualberta.ca/index.php/cjuce-rcepu 
"I gained a skill and a change in attitude"

\section{A Vision of the Targeted Outcomes and Skills}

Some participants reported gaining a vision of ways of practicing that resulted in better patient care and enabled them to reconceptualize both their role as pharmacists and the need for professional advocacy:

I have learned the importance of pharmacy's contribution to the health-care team. This has made me more confident in contributing during ICU interdisciplinary rounds. (P9, Pre-Interview)

Importantly, they reported that this vision came from both peers and subject matter experts (the term "experts" refers to course authors and moderators, as well as to experts in video simulations demonstrating targeted skills):

The moderators were good at saying, "wow, this is a great idea, have you thought about doing this, too, or look[ing] at it a certain way." (P11, Focus Group)

I think that some was also due to the group sharing of experiences and ideas that broke down the feeling of isolation of a community pharmacist. We got feedback on what works for others and new ideas to try as well. (P8, Interview)

This vision translated, for some participants, into a willingness to adopt new practices, which addresses the affective dimension of learning. Participant 6 , for example, spoke about a change in values, attitudes, and motivations:

I have realized that collaborative care delivery is required for me to function as a pharmacist in a primary care network. It is important to ensure that this care continues with providers outside the clinic. This has had the effect of opening my eyes to the possibility of collaborating with others outside the primary care network environment; specifically, community pharmacists. (P6, Pre-Interview)

\section{Support for transfer of learning.}

Supports identified by participants were authentic (i.e., real-world) tools, the modelling of targeted skills and behaviours, and the building of learner confidence:

So, from ADAPT again, the structures, the how-to, and the templates; basically, I now have the tools in my workplace to do what I want to do. (P4, Interview)

I did like the Action Plans, but I think for actually making changes to practice it was the videos of patient interactions. (P10, Interview)

\section{Preparation for Action}

Participants reported that opportunities to reflect on practice (and on themselves as practitioners), set goals, and apply targeted skills to practice helped them transfer new skills:

I found I really fit into the described personality traits of a pharmacist (!) and this helped me to reflect on the way I have been practicing pharmacy and the direction I would like to take as a pharmacist who can take on more responsibility over time for some of my patient's drug therapy. I realize this will not change overnight but small steps will start to lead me in the right direction. (P12, Action Plan)

The Action Plans were good because they made you set a goal. (P7, Interview)

Canadian Journal of University Continuing Education | Vol. 40, No. 2, Fall 2014

Revue canadienne de l'éducation permanente universitaire I vol. 40, n², automne 2014

http://ejournals.library.ualberta.ca/index.php/cjuce-rcepu 
"I gained a skill and a change in attitude"

Every time you practice it, it becomes more comfortable. You go from beginner to novice with repetition and practice and gaining confidence and having structure. All of that helps. (P4, Interview)

\section{Discussion}

Given that the goal of ADAPT is to help pharmacists develop patient care and collaborative skills as well as the confidence to use these skills in practice, these results indicate that the course's transfer-to-practice outcomes were met for study participants. Because applied outcomes are typically associated with face-to-face learning, we next explore the online learning features that helped to facilitate these outcomes in ADAPT.

\section{On Experiential Learning and the Cognitive Apprenticeship Model}

In a mixed-methods evaluation study of ADAPT, Farrell et al. (2013) reported on the aspects of ADAPT that contributed to participant learning and satisfaction in the course. Results indicated that participant learning and satisfaction were enhanced by positive and negative modelling, practice-at-work activities involving course tools and templates, and opportunities for interaction with peers. These elements are drawn from the experiential learning and cognitive apprenticeship models of instruction, and their successful use in the course led investigators to suggest that professional development in pharmacy should focus "less on the development of transmission-oriented online learning programs and more on programs that incorporate principles of experiential learning and cognitive apprenticeship" (Farrell et al., 2013, p. 11). Building on this recommendation, the findings from this study highlight three features from these models that were particularly useful in facilitating practice-oriented outcomes for study participants: first, providing a vision of targeted outcomes and skills; second, providing support to learners to enable them to attain targeted outcomes and skills; and third, preparing learners for action.

\section{Vision}

Kolb (1984) argues that learning occurs most effectively through a four-stage process of "grasping experience and transforming it" (p. 41). Transforming experience is a central concern in courses with practice-oriented outcomes, like ADAPT. In fact, the term "practice change" implies a shift or transformation in learners' ways of understanding and behaving in practice contexts. Results from this study suggest that learners cannot begin to engage in these kinds of transformational experiences without being willing to consider a new vision of what they do and even of who they are as practitioners. In other words, we suggest that the affective domain of learning needs to be explicitly addressed in courses with practice-oriented outcomes. The affective domain of learning involves "feelings, values, appreciations, enthusiasms, motivations, and attitudes" (Clark, 2014, Affective Domain, para 1). Evidence of this kind of learning-specifically, a willingness to engage in new approaches and new self-conceptualizations-was apparent among some study participants:

So I think ADAPT ... has me thinking ... about that change and actually recognizing that this is going to take time and ... maybe giving me a bit more confidence in my interactions with regard to that change. (P6, Focus Group)

Canadian Journal of University Continuing Education | Vol. 40, No. 2, Fall 2014

Revue canadienne de l'éducation permanente universitaire I vol. 40, n², automne 2014

http://ejournals.library.ualberta.ca/index.php/cjuce-rcepu 
It is interesting that in reflecting on making changes to their practice, several participants recognized time as a factor in actualizing change. These types of reflections were typically captured mid-course (in an Action Plan), or immediately post-course (in a focus group), and suggest that once the affective domain is engaged for learners, deeper learning outcomesincluding relating new knowledge to previous experience and applying it in different contexts (Case \& Marshall, 2009; Entwistle, 2005) - are likely to occur over a longer time frame, and even to continue outside the framework of the course. Managing expectations around timelines for implementing changes to practice is therefore an important consideration for learners and course designers alike. It is likely, in other words, that applied, practice-oriented types of outcomes will not occur in a sustained way during the delivery cycle of a course or even immediately at the close of it. Assessment strategies used in the course should therefore reflect appropriate expectations of learners with respect to the achievement of these outcomes, and these expectations should be communicated to learners at the outset of the course. As noted in the Action section, below, lower-risk, "practice-at-work" types of activities could be used in the course to scaffold the later achievement of these kinds of outcomes.

How, then, were "feelings, values, appreciations, enthusiasms, motivations and attitudes" (Clark, 2014, Affective Domain, para 1) addressed in the course? In other words, what helped encourage learners to embrace a new vision of what they do and who they are as practitioners? Study participants identified modelling, whether articulated by peers or provided by experts, as playing the largest role in activating this domain of learning:

I guess I can remember the videos of Margaret, the pharmacist, doing interviews with, I think, diabetic patients. Just watching that kind of interaction, and watching the way she interacted with her patients, was very useful. It made me think, "OK, maybe I can do this." (P7, Interview)

\section{Support}

Modelling also provides learners with the support they need to attain practice-oriented outcomes, as described by the following participant:

[T] here was one [video] where the pharmacist summarizes for the physician. I love to have real words to use. They started their meeting with the physician by saying, "Are you familiar with this patient?" which is the simplest thing to say, but it sort of broke the ice. (P6, Interview)

In addition to modelling, participants also found the provision of authentic or real-world tools, "how-tos," and templates helpful in making changes to practice; in the words of one participant, "[B]asically, I now have the tools in my workplace to do what I want to do" (P4, Interview). Somewhat more surprising, however, was the role that these tools played in building learner confidence:

The idea came from the course - that I needed to look at this as part of my practice. . . . Again, it was the confidence more than anything. OK, now I have the tools that I can use, now I know how to phrase things properly, now I know how to do it without a lot of extra stuff going on that physicians don't read anyway. (P2, Interview)

Study participants consistently reported learner confidence as being the most important factor in supporting workplace practice changes, demonstrated by its prevalence in the data. Factors identified by participants as contributing to learner confidence included: the tools and modelling strategies previously discussed; validation from peers and moderators on discussion boards and from colleagues in the workplace; and a more complete understanding of the role of pharmacy in health care.

Canadian Journal of University Continuing Education | Vol. 40, No. 2, Fall 2014

Revue canadienne de l'éducation permanente universitaire I vol. 40, n², automne 2014

http://ejournals.library.ualberta.ca/index.php/cjuce-rcepu 
"I gained a skill and a change in attitude"

\section{Action}

Collins, Brown, and Holum (1991) argue that the success of cognitive apprenticeship lies in its activity-based approach: "To the degree that readers or listeners are passive, however, they will not learn as much as they would by apprenticeship, because apprenticeship forces them to use their knowledge" (p. 3). Participants reported that "knowledge-in-use" strategies that prepared them for action were important in facilitating the transfer of skills to practice. Strategies in this vein included opportunities for learners to reflect on practice (and on themselves as practitioners), set goals, and apply targeted skills to practise.

The Action Plan (Appendix) was identified as especially useful in preparing participants for action, as it provided a space for learners to reflect on practice, as well as to document intentions for change:

[T] he Action Plans were good as well, just to have a concrete reminder of what you learned in that unit and how you could use it. Like, to think about how you were actually going to apply what you learned rather than just learning and just forgetting about it or not putting it in practice. (P9, Interview)

In addition, practice-at-work activities provided a low-risk way for learners to begin to implement changes in practice and to receive feedback on these changes from workplace colleagues:

Practice. Maybe for me it was getting a little practice in stuff so I got a little touch-up. See, so often as an adult learner, you take a course on the weekend, and then Monday morning, you don't ever look at it again. So it's hard to get it into memory. Whereas, in ADAPT, I got some repetition of stuff that I had done. (P4, Interview)

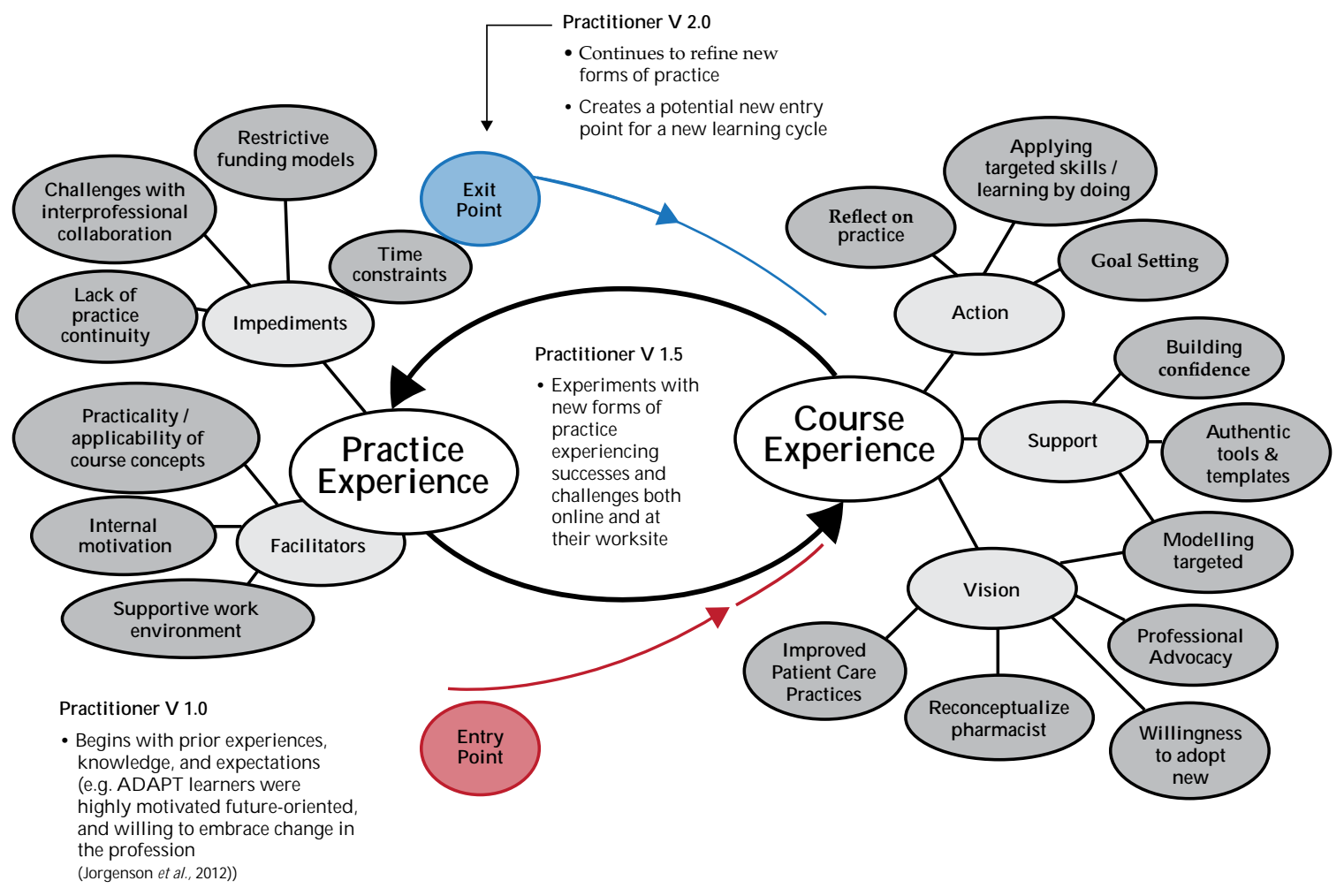

Figure 1: Practice Change Learning Cycle

Canadian Journal of University Continuing Education | Vol. 40, No. 2, Fall 2014

Revue canadienne de l'éducation permanente universitaire I vol. 40, n², automne 2014

http://ejournals.library.ualberta.ca/index.php/cjuce-rcepu 
"I gained a skill and a change in attitude"

\section{Vision-Support-Action: Implications for Course Design}

Our results suggest that the principles of experiential learning and cognitive apprenticeship can be used in fully online, professional development contexts to facilitate the achievement of practice-oriented outcomes. We therefore encourage course designers who seek these types of outcomes to pay particular attention to three key strategies that facilitated these outcomes for the participants in this study: (1) provide learners with a vision of who they are as practitioners and what they do in practice, including allowing opportunities for peers to share this vision; (2) provide learners with support in the attainment of practice-oriented outcomes, including enhancing learner confidence and offering real-world tools and "how-tos"; and (3) prepare learners to take action through opportunities to reflect on practice, set goals, and participate in low-risk, practice-at-work activities (Figure 1). These strategies are consistent with Caffarrella's (2002) recommendations on designing learning to facilitate practice transfer. Caffarrella underscores, for example, the importance of (i) shaping learners' dispositions towards learning and applying new knowledge; (ii) designing content that is application focused (relevant, useful, practical); (iii) building on the prior experiences of learners; and (iv) using active learning strategies extensively. These principles align well with the vision-support-action framework we propose here.

\section{Vision-Support-Action and Cognitive Apprenticeship}

Cognitive apprenticeship includes the strategies of modelling, coaching, scaffolding, articulation, reflection, and exploration (Collins, Brown, \& Holum, 1991). Modelling emerged as a particularly important strategy for the learners in our study, both in the preliminary phase of the course by helping them embrace a new vision of themselves as practitioners, as well as in later parts of the course by helping them build confidence to implement practice changes. Table 1 summarizes the cognitive apprenticeship strategies, how they map onto the vision-support-action framework we propose here, and how they were operationalized in the ADAPT course.

Table 1: Implementation of Cognitive Apprenticeship Framework in ADAPT

\begin{tabular}{|c|c|c|}
\hline $\begin{array}{l}\text { Cognitive Apprenticeship } \\
\text { Strategy }\end{array}$ & $\begin{array}{l}\text { Vision-Support-Action } \\
\text { Framework }\end{array}$ & Implementation in ADAPT \\
\hline $\begin{array}{l}\text { Modelling } \\
\text { (Experts make target } \\
\text { outcomes visible to learners) }\end{array}$ & $\begin{array}{l}\text { Provides learners with } \\
\text { vision } \\
\text { Provides learners with } \\
\text { support (including } \\
\text { confidence) }\end{array}$ & $\begin{array}{l}\text { - Video simulations of } \\
\text { experts performing a task } \\
\text { - Content presentations in } \\
\text { which experts break down } \\
\text { key concepts and skills }\end{array}$ \\
\hline $\begin{array}{l}\text { Coaching } \\
\text { (Experts provide encourage- } \\
\text { ment, feedback, advice to } \\
\text { learners) }\end{array}$ & $\begin{array}{l}\text { Provides learners with } \\
\text { support }\end{array}$ & $\begin{array}{l}\text { Moderators provide assis- } \\
\text { tance to learners having } \\
\text { difficulty, provide encour- } \\
\text { agement and advice on } \\
\text { discussion boards and } \\
\text { feedback on Action Plans } \\
\text { - Peers provide encourage- } \\
\text { ment and shared practice } \\
\text { experiences on discus- } \\
\text { sion boards, boosting } \\
\text { confidence }\end{array}$ \\
\hline
\end{tabular}

Canadian Journal of University Continuing Education | Vol. 40, No. 2, Fall 2014

Revue canadienne de l'éducation permanente universitaire I vol. 40, n², automne 2014

http://ejournals.library.ualberta.ca/index.php/cjuce-rcepu 
"I gained a skill and a change in attitude"

\begin{tabular}{ll}
$\begin{array}{l}\text { Cognitive Apprenticeship } \\
\text { Strategy }\end{array}$ & $\begin{array}{l}\text { Vision-Support-Action } \\
\text { Framework }\end{array}$ \\
$\begin{array}{l}\text { Scaffolding } \\
\text { (Experts provide support }\end{array}$ & $\begin{array}{l}\text { Provides learners with } \\
\text { support }\end{array}$ \\
$\begin{array}{l}\text { for tasks; support dimin- } \\
\text { ishes as learners acquire } \\
\text { skills) }\end{array}$ & Prepares learners for action \\
\hline
\end{tabular}

Implementation in ADAPT skills)

\section{Articulation}

(Learners articulate their knowledge, reasoning, and problem-solving processes)
Prepares learners for action

- Learners articulate how they plan to use their knowledge in the Action Plan

- Learners share problemsolving strategies and practices with peers on discussion boards

Prepares learners for action
- Learners articulate problem-solving strategies in Action Plan; moderators provide feedback

- Learners share problemsolving strategies with peers on discussion boards

\section{Exploration}

(Learners engage in problem-solving)
Prepares learners for action
- Learners practice new skills in low-risk ways in workplace and bring experiences back to peers on discussion boards for reflection and discussion

\section{Barriers to Implementing Changes}

Caffarella (2002) makes the point that a well-constructed course with engaging and relevant content, activities, and assessments will not on its own guarantee the sustained achievement of practice-oriented outcomes. This was borne out in our experience as well. Table 2 outlines the most significant barriers to practice change reported by study participants, and how these relate to the factors Caffarrella outlines as primary impediments to practice transfer.

Canadian Journal of University Continuing Education | Vol. 40, No. 2, Fall 2014

Revue canadienne de l'éducation permanente universitaire I vol. 40, n² 2, automne 2014

http://ejournals.library.ualberta.ca/index.php/cjuce-rcepu 
"I gained a skill and a change in attitude"

Table 2: Barriers to Practice Transfer

\begin{tabular}{ll} 
Participant-Cited Barrier & Caffarella's Barriers to Practice Transfer \\
\hline $\begin{array}{l}\text { Lack of continuity of practice } \\
\text { - A concern for participants who did } \\
\text { not have a regular practice environment } \\
\text { (e.g., a relief pharmacist) }\end{array}$ & $\begin{array}{l}\text { Course participants } \\
\text { - Possess little power or authority to } \\
\text { implement change }\end{array}$ \\
$\begin{array}{ll}\text { Time to implement changes } & \text { Changes required to apply learning } \\
\text { - Time requirements for change are not } \\
\text { considered or are unrealistic }\end{array}$ \\
$\begin{array}{l}\text { Interprofessional challenges (in the } \\
\text { work environment) }\end{array}$ & $\begin{array}{l}\text { Organizational context } \\
\text { - Climate of resistance to innovation or } \\
\text { change is evident }\end{array}$ \\
working in health teams & $\begin{array}{l}\text { Support from peers, supervisors, and } \\
\text { managers is weak or non-existent }\end{array}$ \\
$\begin{array}{l}\text { Restrictive funding models } \\
\text { Dependent on the province of practice, as } \\
\text { funding models differ across provinces }\end{array}$ & $\begin{array}{l}\text { Organizational context } \\
\text { - Rewards system works against applying } \\
\text { what has been learned }\end{array}$ \\
& $\begin{array}{l}\text { Financial and other resources are } \\
\text { inadequate }\end{array}$ \\
\end{tabular}

\section{ConCLusion}

The results of this case study suggest that the experiential learning and cognitive apprenticeship models of instruction can be effectively employed in online CPE courses to promote the achievement of practice-oriented outcomes (Farrell et al., 2013). Participants identified three features from these models as useful in facilitating practice-oriented outcomes: providing learners with a vision of targeted outcomes and skills, support to enable them to attain targeted outcomes and skills, and explicit preparation for action. Modelling emerged as a particularly effective strategy for study participants, playing a role in creating a vision for targeted outcomes, in supporting the acquisition of these outcomes, and in enhancing learner confidence.

Canadian Journal of University Continuing Education | Vol. 40, No. 2, Fall 2014

Revue canadienne de l'éducation permanente universitaire I vol. 40, n², automne 2014

http://ejournals.library.ualberta.ca/index.php/cjuce-rcepu 


\section{REFERENCES}

Burnard, P. (1991). A method of analysing interview transcripts in qualitative research. Nurse Education Today, 11, 461-466.

Caffarella, R. S. (2002). Planning programs for adult learners: A practical guide for educators, trainers, and staff developers (2nd ed.). San Francisco, CA: Jossey Bass.

Case, J., \& Marshall, D. (2009). Approaches to learning. In M. Tight, J. Huisman, K. H. Mok, \& C. Morphew (Eds.), The Routledge international handbook of higher education (p. 9-21). London, UK: Routledge Falmer.

Clark, D. (2014, July 7). Bloom's taxonomy of learning domains. Retrieved from http://www.nwlink .com/ donclark/hrd/bloom.html

Collins, A., Brown, J., \& Holum, A. (1991). Cognitive apprenticeship: Making thinking visible. American Educator, 6, 38-46.

Creswell, J. (1998). Qualitative inquiry and research design. Thousand Oaks, CA: Sage.

Entwistle, N. (2005). Contrasting perspectives on learning. In F. Marton, D. Hounsell, \& N. Entwistle (Eds.), The experience of learning: Implications for teaching and studying in higher education (3rd Internet ed.). Edinburgh, UK: University of Edinburgh, Centre for Teaching, Learning and Assessment. Retrieved from http://www.ed.ac.uk/schools-departments/ institute-academic-development/learning-teaching/staff/advice/researching/publications/ experience-of-learning?language $=\mathrm{pl}$

Farrell, B., Dolovich, L., Austin, Z., \& Sellors, C. (2010). Mentoring pharmacists as they integrated into family practice: Practical experience from the IMPACT project. Canadian Pharmacists Journal, 143, 28-36.

Farrell, B., Dolovich, L., Emberley, P., Gagné, M. A., Jennings, B., Jorgenson, D., . . Woloschuk, D. (2012). Designing a novel continuing education program for pharmacists: Lessons learned. Canadian Pharmacists Journal, 145(4), e7-e16. Available from http://cph.sagepub .com/content/145/4/e7.full.pdf+html

Farrell, B., Jennings, B., Ward, N., Zeni-Marks, P., Kennie, N., Dolovich, L., . . Gubbels, A. (2013). Evaluation of a pilot learning primary healthcare skills training program for pharmacists. Currents in Pharmacy Teaching and Learning, 5(6), 580-592.

Jorgenson, D., Gubbels-Smith, A., Farrell, B., Ward, N., Dolovich, L., \& Jennings, B. (2012). Characteristics of pharmacists who enrolled in the pilot ADAPT education program: Implications for practice change. Canadian Pharmacists Journal, 145(6), 260-263.

Kolb, D.A. (1984). Experiential learning: Experience as the source of learning and development. Englewood Cliffs, NJ: Prentice-Hall.

Kolb, D. A., \& Fry, R. (1975). Toward an applied theory of experiential learning. In C. Cooper (Ed.), Theories of group process. London, UK: John Wiley.

Krefting, L. (1991, March). Rigor in qualitative research: The assessment of trustworthiness. The American Journal of Occupational Therapy, 45(3), 214-222.

Canadian Journal of University Continuing Education | Vol. 40, No. 2, Fall 2014

Revue canadienne de l'éducation permanente universitaire I vol. 40, n², automne 2014

http://ejournals.library.ualberta.ca/index.php/cjuce-rcepu 
"I gained a skill and a change in attitude"

Miller, M. (2005). Teaching and learning in affective domain. In M. Orey (Ed.), Emerging perspectives on learning, teaching, and technology. Bloomington, IN: Association for Educational Communications and Technology. Retrieved from http://epltt.coe.uga.edu/index. php?title=Teaching_and_Learning_in_Affective_Domain

Stake, R. E. (1995). The art of case study research. Thousand Oaks, CA: Sage.

Task Force on a Blueprint for Pharmacy. (2008). Blueprint for pharmacy: The vision for pharmacy. Ottawa, ON: Canadian Pharmacists Association. Retrieved from www.blueprintforpharmacy.ca

\section{BIOGRAPHIES}

Pia Zeni Marks is an online learning consultant at the Centre for Extended Learning, University of Waterloo. Her pedagogical pursuits include designing online courses that are engaging, outcomes focused, and evidence based. Research interests include studies in online user experience, and the transfer of online learning experiences to real-world contexts.

Pia Zeni Marks est consultant en apprentissage en ligne auprès du Centre for Extended Learning (Centre de formation continue) de l'Université de Waterloo. Parmi ses objectifs pédagogiques on trouve la conception de cours en ligne qui sont captivants, axés sur les résultats et fondés sur des preuves. Ses recherches portent sur les études de l'expérience de l'utilisateur en ligne et sur le transfert d'expériences d'apprentissage en ligne vers des contextes du monde réel.

Brad Jennings is an online learning consultant with the Centre for Extended Learning and educational researcher and developer at the School of Pharmacy, University of Waterloo. His research interests include the organizational use of knowledge and practice change.

Brad Jennings est consultant en apprentissage en ligne auprès du Centre for Extended Learning (Centre de formation continue), chercheur en éducation et développeur à la School of Pharmacy (École de pharmacie) de l'Université de Waterloo. Ses intérêts de recherche comprennent l'utilisation de l'organisation de la connaissance et la pratique du changement.

Barbara Farrell is an assistant professor, Department of Family Medicine, University of Ottawa and adjunct assistant professor, School of Pharmacy, University of Waterloo. She is a scientist with the Bruyère Research Institute, Ottawa, Ontario. Her research interests include the exploration of interprofessional care for medication management and approaches to reducing polypharmacy in the elderly.

Barbara Farrell est professeure adjointe au Département de médecine familiale de l'Université d'Ottawa et professeure auxiliaire adjointe à la School of Pharmacy (Faculté de pharmacie) de l'Université de Waterloo. Elle est aussi chercheuse à l'Institut de recherche Bruyère à Ottawa, en Ontario. Ses intérêts de recherche portent sur l'exploration de soins interprofessionnels pour la gestion des médicaments et sur des approches à la réduction de la polymédication chez les personnes âgées.

Natalie Kennie-Kaulbach is the second year skills lab coordinator at the College of Pharmacy, Dalhousie University. For 13 years, she was a clinical pharmacist in a family medicine practice in Ontario. Her research interests include integration of pharmacists into primary care and skills required to meet new scope of practice changes; her education interests include learning design.

Natalie Kennie-Kaulbach en est à sa deuxième année de coordination du Skills Lab (laboratoire de compétences) du College of Pharmacy (Collège de pharmacie) de l'Université Dalhousie. Auparavant, elle a été pharmacienne clinicienne en pratique de la médecine familiale

Canadian Journal of University Continuing Education | Vol. 40, No. 2, Fall 2014

Revue canadienne de l'éducation permanente universitaire I vol. 40, n², automne 2014

http://ejournals.library.ualberta.ca/index.php/cjuce-rcepu 
en Ontario pendant 13 ans. Ses intérêts de recherche portent sur l'intégration des pharmaciens en soins primaires et sur les compétences nécessaires pour répondre à de nouvelles possibilités de changements de pratiques, tandis que ses intérêts en éducation comprennent la conception d'apprentissage.

Derek Jorgenson is an associate professor of pharmacy in the College of Pharmacy and Nutrition and the College of Medicine at the University of Saskatchewan and is also an adjunct professor at the University of Ottawa School of Nursing. He is pursuing primary care health services utilization research related to medication management and the role of pharmacists.

En plus d'être professeur adjoint à l'Ecole des sciences infirmières de l'Université d'Ottawa, Derek Jorgenson est professeur agrégé de pharmacie au College of Pharmacy and Nutrition (Collège de pharmacie et de nutrition) et au College of Medicine (Collège de médecine) de l'Université de la Saskatchewan. Il poursuit présentement des recherches sur l'utilisation de services de soins de santé primaires en lien avec la gestion des médicaments et le rôle des pharmaciens.

Jane Pearson Sharpe is a research assistant with the Ontario Pharmacy Research Collaboration (OPEN) working with the Gender and Vulnerable Populations and the Pharmacists as Immunizers projects. Previously, she worked as a research assistant with the Centre for Extended Learning, University of Waterloo.

Jane Pearson Sharpe est assistante de recherche de l'Ontario Pharmacy Research Collaboration (collaboration de recherche en pharmacie de l'Ontario ou OPEN) et travaille sur des projets visant les populations féminines et vulnérables, ainsi que les pharmaciens en tant que vaccinateurs. Auparavant, elle a travaillé comme assistante de recherche avec le Centre for Extended Learning (Centre de formation continue) de l’Université de Waterloo.

Nancy Waite is associate director, Practice-Based Education and Professional Outreach, School of Pharmacy, University of Waterloo. Her research explores the impact of pharmacists' scope of practice changes on health outcomes, as well as assessing novel curricula to ensure graduates are well prepared to provide medication management services in an evolving healthcare landscape.

Nancy Waite est directrice associée à la School of Pharmacy (l'École de pharmacie, une école fondée sur la pratique) de l’Université de Waterloo. Sa recherche examine les effets des changements de la pratique des pharmaciens sur les résultats de santé, et évalue de nouveaux programmes d'études afin de s'assurer que les diplômés sont bien préparés à fournir des services de gestion des médicaments dans un milieu de soins de santé en pleine évolution.

Canadian Journal of University Continuing Education | Vol. 40, No. 2, Fall 2014

Revue canadienne de l'éducation permanente universitaire I vol. 40, n², automne 2014

http://ejournals.library.ualberta.ca/index.php/cjuce-rcepu 


\section{ApPEndix}

Action Plan

Take a moment to consider your learning objectives and what you have learned to date. What would you like to change? Plan how you would like to implement those changes using the following form to set personal ADAPT goals.

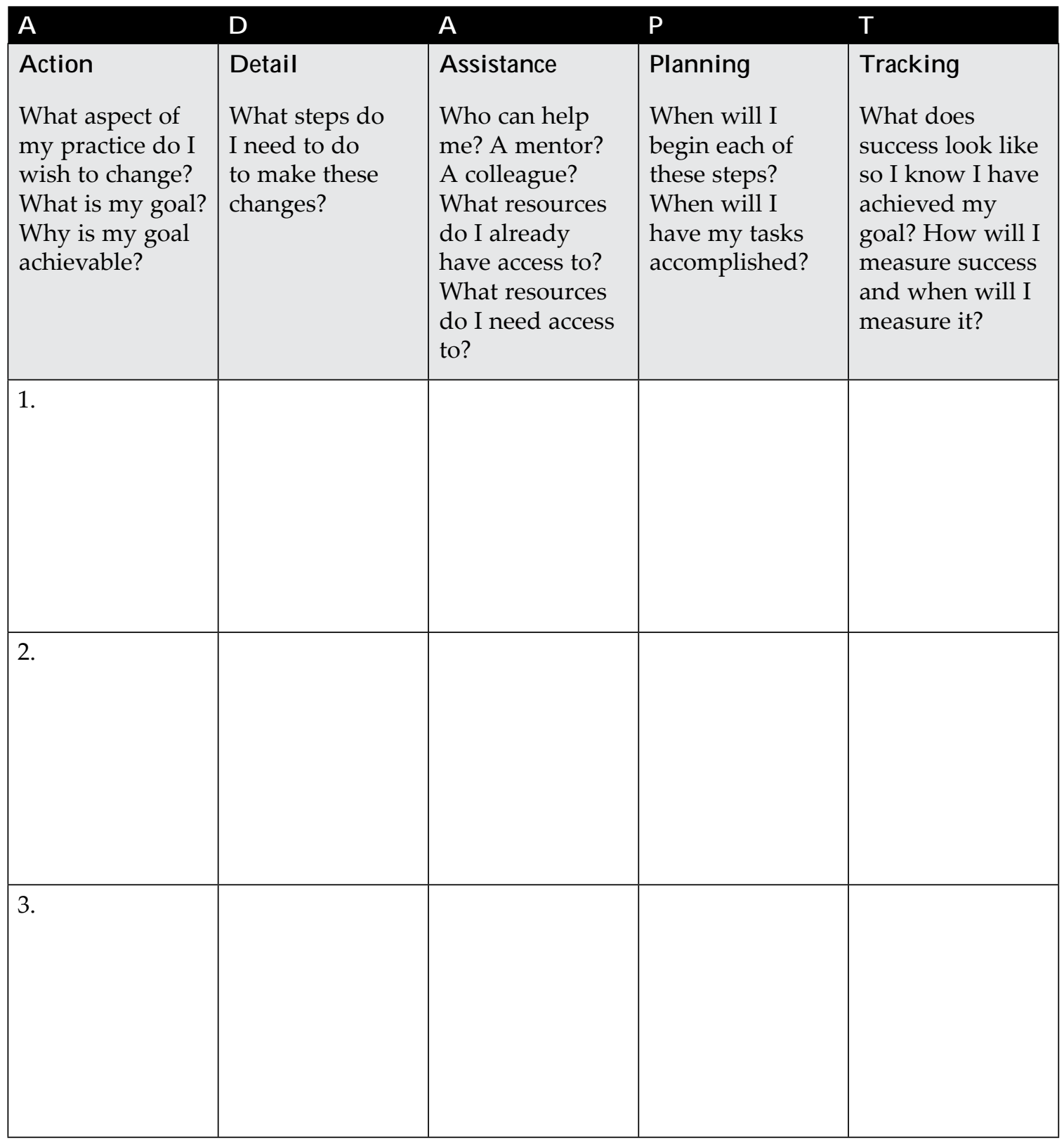

(C) Canadian Pharmacists Association 2011

Canadian Journal of University Continuing Education | Vol. 40, No. 2, Fall 2014

Revue canadienne de l'éducation permanente universitaire I vol. 40, n², automne 2014

http://ejournals.library.ualberta.ca/index.php/cjuce-rcepu 